\title{
Marine ichthyofauna of Santa Catarina Island, Southern Brazil: checklist with comments on the species
}

\author{
Gisela Costa Ribeiro $^{I}$, André Pereira Cattani ${ }^{2,3}$, Mauricio Hostim-Silva ${ }^{4}$, Leandro Clezar ${ }^{l}$, Ana Carolina dos

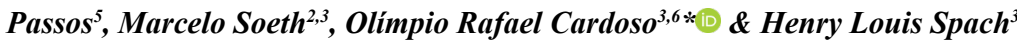 \\ ${ }^{1}$ Universidade Federal de Santa Catarina, Núcleo de Estudos do Mar, CEP 88040-900, \\ Florianópolis, SC, Brasil \\ ${ }^{2}$ Universidade Federal do Paraná, Centro de Estudos do Mar, Programa de Pós-Graduação em Sistemas \\ Costeiros e Oceânicos, CEP 83255-976, Pontal do Paraná, PR, Brasil \\ ${ }^{3}$ Universidade Federal do Paraná, Centro de Estudos do Mar, Laboratório de Ecologia de Peixes Beira-mar, \\ CEP 83255-971, Pontal do Paraná, PR, Brasil \\ ${ }^{4}$ Universidade Federal do Espírito Santo, Departamento de Ciências da Saúde, Biológicas e Agrárias, CEP \\ 29932-540, São Mateus, ES, Brasil \\ ${ }^{5}$ Universidade Federal do Espírito Santo, Departamento de Oceanografia, Programa de Pós-Graduação em \\ Oceanografia Ambiental, CEP 29075-910, Vitória, ES, Brasil \\ ${ }^{6}$ Universidade Federal do Paraná, Programa de Pós-Graduação em Zoologia, CEP 80060-000, \\ Curitiba, PR, Brasil \\ *Corresponding author: Olimpio Rafael Cardoso,e-mail: rafael.bioufrgs@gmail.com
}

RIBEIRO, G.C., CATTANI, A.P., HOSTIM-SILVA, M., CLEZAR, L., PASSOS, A.C., SOETH, M., CARDOSO, O.R., SPACH, H.L. Marine ichthyofauna of Santa Catarina Island, Southern Brazil: checklist with comments on the species. Biota Neotropica. 19(3): e20180684. http://dx.doi.org/10.1590/1676-0611-BN-2018-0684

\begin{abstract}
This study aimed to present a checklist of marine fishes from coastal environments of the Island of Santa Catarina, including comments on the zoogeographic affinities, conservation status of each species, and functional groups. A total of 169 fish species belonging to 30 orders and 58 families were recorded. The most speciose families were Sciaenidae, Carangidae and, Engraulidae, representing 26,62\% of the recorded species. Anchoa was the richest genus, followed by Sphoeroides and Cynoscion. Most of the species have their distribution limited to the western Atlantic, and two groups of fish were distinguished according to the species distributions: 1) species occurring in the Caribbean and in the Brazilian Province; and 2) Transatlantic species. Thirteen species are critically threatened, 10 are overexploited on the Brazilian coast, and 2 are threatened by extinction. Most of the species are either marine stragglers or marine migrants, and most of them are zoobenthivores, piscivores, or both. Keywords: fish, species list, Southwest Atlantic.
\end{abstract}

\section{Ictiofauna marinha da Ilha de Santa Catarina, Sul do Brasil: lista com comentários sobre as espécies}

Resumo: Este estudo teve como objetivo apresentar uma lista de peixes marinhos de ambientes costeiros da Ilha de Santa Catarina, incluindo comentários sobre as afinidades zoogeográficas, estado de conservação de cada espécie e grupos funcionais. Um total de 169 espécies de peixes, pertencentes a 30 ordens e 58 famílias, foram registradas. As famílias mais especiosas foram Sciaenidae, Carangidae e Engraulidae, representando 26,62\% das espécies registradas. Anchoa foi o gênero mais rico, seguido por Sphoeroides e Cynoscion. A maioria das espécies tem sua distribuição limitada ao Atlântico ocidental, e dois grupos de peixes foram distinguidos de acordo com as distribuições de espécies: 1) espécies ocorrentes no Caribe e na Província Brasileira; e 2) espécies Transatlânticas. Treze espécies estão criticamente ameaçadas, 10 são superexploradas na costa brasileira e 2 estão ameaçadas de extinção. A maioria das espécies é composta por visitantes marinhos ou migrantes marinhos, sendo a maioria deles zoobentívoros, piscívoros ou ambos.

Palavras-chave: peixe, lista de espécies, Atlântico Sudoeste. 


\section{Introduction}

Diversity of estuarine environments is threatened by anthropogenic activities such as predatory fishing and port construction and activities, which can lead to species introduction, habitat loss, and environmental pollution. Thus, the compilation of fish records from South Atlantic is important because it improves the understanding of the geographic distribution and macroecological aspects of marine and estuarine fishes (Barletta \& Blaber 2007), and assists in strategic planning for the conservation of the species as well (Barletta et al., 2010).

Coastal and estuarine areas are nurseries for the aquatic biota. Despite the great variety of ecosystems, knowledge about fish assembly from the Island of Santa Catarina is scarce. Only a few studies have been conducted, which focused on spatio-temporal patterns in specific environments (Clezar et al. 1997, Ribeiro et al. 1997, Ribeiro et al. 1999, Cartagena et al. 2011, Soeth 2015). Therefore, this study aimed to present a checklist of marine fishes from different coastal environments of the Island of Santa Catarina through a compilation of unpublished and published information from the literature. In addition, comments on the zoogeographic affinities, conservation status of each species, and functional groups are also provided.

\section{Material and Methods}

\section{Study Site}

The Island of Santa Catarina (28 $37^{\prime} \mathrm{S} ; 4^{\circ} 27^{\prime} \mathrm{W}$ ) (Figure 1) is located near the tropical/subtropical border, and parallelly and contiguously to the continental margin. It has an elongated shape (N-NE/S-SW), an area of $431 \mathrm{~km}^{2}$, and a coastline length of $180 \mathrm{~km}$ (Sierra de Ledo 1997). It is an insular environment composed by a variety of ecosystems, such as mangroves, lagoons, sandy beaches and rocky shores. Regarding its climate, the region is humid subtropical (Köppen Cfa), characterized by a well-defined seasonality, with the rainy period in the spring and summer (September to March, with monthly mean of $172 \mathrm{~mm}$ ), and the dry period in the autumn and winter (April to August, with monthly mean of $74 \mathrm{~mm}$ ) (Fonseca 2002).

The predominant wind patterns on the island is associated with the action of the Tropical Atlantic and Polar Atlantic air masses, which produce winds from the north and south quadrants, respectively (Abreu de Castilhos and Gré 1997). According to these authors, the dominant waves are mainly from the northeast, southeast and south, with the most significant heights coming from the south. The island also has semidiurnal tides (mean amplitude $=0.52 \mathrm{~m}$ ) in the interior of the bays in the area near the island (Soriano-Sierra 1997).

\section{Data Collection}

This work was based on the compilation of information available in the literature as well as unpublished data obtained by the authors during the last 30 years. Former data was obtained from Google Scholar, Web of Science, and Portal de Periódicos da Coordenação de Aperfeiçoamento de Pessoal de Nível Superior (CAPES). We searched for articles focusing on fish species from different environments (e.g. bays, lagoons and mangroves) of the Island of Santa Catarina (e.g. Clezar et al.1997, Nemar 1999, Daura Jorge 2007, Cartagena et al. 2011, Soeth 2015, Cattani et al., 2016a, Cattani et al., 2016b, Cattani et al., 2018).

\section{Data Analysis}

Taxonomic classification and nomenclature of fish species followed Craig \& Hastings (2007), Smith \& Craig (2007), Eschmeyer (2013), Carvalho-Filho et al. (2010), Figueiredo et al. (2010), Menezes et al. (2010) Nelson et al. (2016) and Betancur-R et al. (2017). Mugil sp. was used for species usually identified under the invalid name Mugil gaimardianus (Menezes et al. 2003). Orders and families are listed in alphabetical order, and species of each family are presented in alphabetical order as well.

In order to analyze the zoogeographic affinities, we classified each species according to the literature (Floeter et al. 2008, Luiz Jr. et al. 2008, Eschmeyer 2013, Froese \& Pauly 2018) in the following categories of geographic distribution: $\mathrm{CT}=$ Circumtropical, $\mathrm{TA}=$ Transatlantic (occurs in western and eastern Atlantic Ocean), WA = Western Atlantic (occurs in northern and southern Atlantic Ocean), SWA = Southwestern Atlantic (occurs from northern Brazil to Argentina), SSWA = Southern Southwestern Atlantic (species with temperate affinities that occurs in Argentina, Uruguay, and southern and southeastern Brazil), $\mathrm{Ca}=$ Caribbean (from Florida to Venezuela), $\mathrm{Br}=$ Brazilian Province (area between the Orinoco Delta in Venezuela and Santa Catarina state, in Brazil: sensu Briggs 1995; Floeter \& Gasparini 2000) and EP = Eastern Pacific. Species were also classified according to the type of environment they were collected (bays, lagoons and mangroves).

Fish species were classified into the following estuarine functional groups, proposed by Elliot et al. (2007): marine stragglers (MS) (species that spawn at sea and enter estuaries in low numbers; stenohaline environments with salinity around 35), marine migrants (MM) (species that spawn at sea and enter estuaries in large numbers as juveniles; euryhaline environments), estuarine species (ES), anadromous (AN) (species that undergo their growth at sea and migrate into rivers to spawn), amphidromous (AM) (migrate between the sea and freshwater; migration in neither direction is related to reproduction), and freshwater migrants (FM) (found in moderate numbers in estuaries and oligohaline environments). Species were also classified into trophic functional groups (Elliot et al. 2007): zooplanktivore (ZP) (feeds on zooplankton), detritivore (DV) (feeds on detritus and/or microphytobenthos), herbivore (HV) (grazes on macroalgae and macrophytes or phytoplankton), omnivore (OV) (feeds on filamentous algae, macrophytes, periphyton, epifauna and infauna), piscivore (PV) (feeds on finfish and large nektonic invertebrates), zoobenthivore (ZB) (feeds on invertebrates that live just above, on or in the sediment) and opportunist (OP) (feeds on a diverse range of food).

The conservation status of each species followed the International Red List of threatened species proposed by the IUCN (2018), by the Brazilian red list of threatened species proposed by the MMA (2016), and by regional conservation status based on the list proposed by State Council of the Environment of Santa Catarina - CONSEMA (2011). All specimens were deposited in the fish collection of the Núcleo de Estudos do Mar - NEMAR, Universidade Federal de Santa Catarina.

\section{Results}

The ichthyofauna of the Island of Santa Catarina comprises 169 species (165 Actinopterygii and 4 Elasmobranchii) distributed into 30 orders and 58 families. Perciformes was the most speciose order (32), followed by Clupeiformes (18), Pleuronectiformes (14) and 


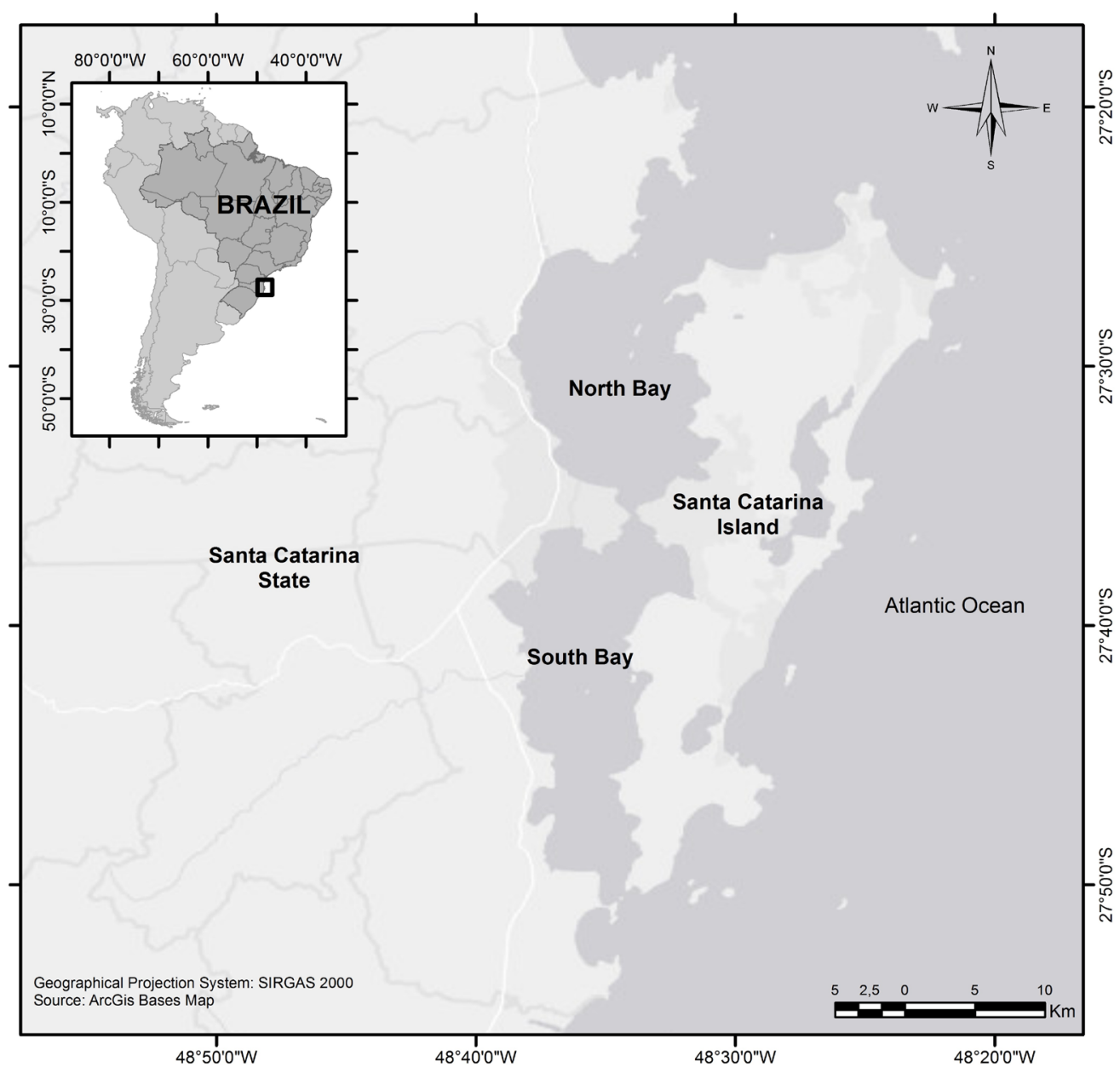

Figure 1. Location of the Island of Santa Catarina, Southern Brazil.

Tetraodontiformes (13) (Table 1). Concerning the families, Sciaenidae was the most recorded (20), followed by Carangidae (14), Engraulidae (11), Epinephelidae and Gobiidae (8 each). Anchoa, Sphoeroides and Cynoscion were the richest genera, with 6, 5 and 4 species, respectively.

Regarding the geographic distribution, 37,86\% (64) occur in the Western North Atlantic, 14,20\% (24) occur on both sides of the Atlantic, $13,01 \%$ (22) occur in the Caribbean and in the Brazilian Province, 9,46\% (16) occur only in the Southern Southwestern Atlantic, 5,91\% (10) occur in the Caribbean and in the Southwestern Atlantic, 4,73\% (8) are distributed in tropical areas worldwide, 4,14\% (7) occur only in the Southwestern Atlantic, 3,55\% (6) occur only in the Brazilian Province, $2,36 \%$ (4) occur in the Western Atlantic and in the Eastern Pacific, 0,59\% (1) occur in the Brazilian Province and in the Southwestern Atlantic and $1,18 \%$ (2) occur on both sides of the Atlantic and in the Eastern Pacific.

Fifty nine species (34.91\%) were classified as marine stragglers (MS), $51(30,17 \%)$ as marine migrants (MM), $19(11,24 \%)$ as estuarine (ES), and five species $(2,95 \%)$ as amphidromous. Each of the other functional groups (anadromous, catadromous, estuarine migrant, estuarine resident, freshwater migrant and semi-catadromous) accounted for less than $2 \%$. Twenty-nine species $(17,15 \%)$ did not fit in any category due to the lack of information available in the literature (Table 1).
Regarding the trophic functional groups, seventy seven species $(45,56 \%)$ were classified as zoobentivorous, twenty-seven species $(15,97 \%)$ as piscivorous, sixteen $(9,46 \%)$ as zooplanktivore, and sixteen $(9,46 \%)$ as piscivorous and zoobenthivore. Each of the other trophic functional groups (detritivores, herbivores, opportunists and omnivores) accounted for less than $3 \%$. Twenty one species $(12,42 \%)$ did not fall into any category due to lack of information in the literature. Concerning the type of environment each species was found, thirty-four species $(20,11 \%)$ were recorded in bays, lagoons and mangroves, fifty $(29.58 \%)$ only in bays, twenty $(11.83 \%)$ only in lagoons, and three $(1.74 \%)$ only in mangroves (Table 1).

One hundred and forty-eight species that inhabit the Island of Santa Catarina are listed in the IUCN red list (2018), representing $87.57 \%$ of all species identified. Ten species $(5.78 \%$ of the total) are listed in the MMA red list (2016), and nine species are present in both lists. Of the 148 IUCN red list species, 126 are classified as least concern, nine as vulnerable, six as near threatened and seven with deficient data. Of the ten species listed in the MMA red list, Epinephelus itajara and Gymnura altavela are categorized as critically endangered, Epinephelus marginatus, Epinephelus morio, Hyporthodus niveatus, Mycteroperca bonaci, Hippocampus reidi and Zapteryx brevirostris as vulnerable, and 
Table 1. Taxonomic classification of the ichthyofauna recorded on the Island of Santa Catarina, Brazil. Geographic Distribution: $\mathrm{CT}=\mathrm{Circumtropical}$; TA $=$ Transatlantic; WA = Western Atlantic; SWA = Southwestern Atlantic; SSWA = Southern Southwestern Atlantic; $\mathrm{Ca}=\mathrm{Caribbean} ; \mathrm{Br}=\mathrm{Brazilian} \mathrm{Province} ; \mathrm{EP}=$ Eastern Pacific. Estuarine use and functional groups (EUFG): MS = marine stragglers; $\mathrm{MM}=$ marine migrants; $\mathrm{ES}=$ estuarine species; $\mathrm{AN}=$ anadromous; $\mathrm{AM}$ $=$ amphidromous; $\mathrm{FM}=$ freshwater migrants. Trophic functional groups $(\mathrm{TFG}): \mathrm{ZP}=$ zooplanktivore; $\mathrm{DV}=$ detritivore; $\mathrm{HV}=$ herbivore; $\mathrm{OV}=$ omnivore; $\mathrm{PV}=$ piscivore; $\mathrm{ZB}=$ zoobenthivore; $\mathrm{OP}=$ opportunist. Conservation status according to the international list proposed by IUCN (2018), Brazilian red list proposed by MMA (2016) and to regional list proposed by CONSEMA (2011): $\dagger \dagger=$ overexploited; $\S=$ vulnerable; $\$=$ near threatened; $\bullet=$ critically endangered; $\dagger=$ endangered; $*=$ least concern; $\#=$ data deficient

\begin{tabular}{|c|c|c|c|c|c|c|c|}
\hline List of Species & $\begin{array}{c}\text { Geographic } \\
\text { Range }\end{array}$ & Bays & Lagoons & Mangroove & EUFG & TFG & Voucher number \\
\hline \multicolumn{8}{|l|}{ Acanthuriformes } \\
\hline \multicolumn{8}{|l|}{ Sciaenidae } \\
\hline Bairdiella ronchus (Cuvier, 1830)* & $\mathrm{Ca}+\mathrm{Br}$ & $\mathrm{x}$ & & $\mathrm{x}$ & MM & PV & SCIA 2010.001.PIS 493 \\
\hline Ctenosciaena gracilicirrhus (Metzelaar, 1919)* & $\mathrm{Ca}+\mathrm{Br}$ & $\mathrm{x}$ & & & MS & ZB & SCIA 1982.025.PIS517 \\
\hline Cynoscion jamaicensis (Vaillant \& Bocourt, 1883)* & $\mathrm{Ca}+\mathrm{SWA}$ & $\mathrm{x}$ & & $\mathrm{x}$ & MM & $\mathrm{PV} / \mathrm{ZB}$ & SCIA 1983.038.PIS530 \\
\hline Cynoscion leiarchus (Cuvier, 1830)* & $\mathrm{Ca}+\mathrm{Br}$ & $\mathrm{x}$ & & $\mathrm{x}$ & MS & $\mathrm{PV}$ & SCIA 1988.089.PIS581 \\
\hline Cynoscion microlepidotus (Cuvier, 1830)* & $\mathrm{Br}$ & $\mathrm{x}$ & & $\mathrm{x}$ & MS & & SCIA 1998.104.PIS596 \\
\hline Isopisthus parvipinnis (Cuvier, 1830)* & $\mathrm{Ca}+\mathrm{Br}$ & $\mathrm{x}$ & & $\mathrm{x}$ & MM & ZB & SCIA 2011.132.PIS624 \\
\hline Larimus breviceps Cuvier, $1830^{*}$ & $\mathrm{Ca}+\mathrm{Br}$ & $\mathrm{x}$ & & & MS & ZB & SCIA 2011.133.PIS625 \\
\hline Micropogonias furnieri (Desmarest, 1823) $\dagger \dagger / *$ & $\mathrm{Ca}+\mathrm{SWA}$ & $\mathrm{x}$ & $\mathrm{x}$ & $\mathrm{x}$ & MM & $\mathrm{ZB}$ & SCIA 1988.084.PIS576 \\
\hline Odontoscion dentex (Cuvier, 1830)* & WA & $\mathrm{x}$ & & & & ZB & \\
\hline Paralonchurus brasiliensis (Steindachner, 1875)* & $\mathrm{Ca}+\mathrm{SWA}$ & $\mathrm{x}$ & $\mathrm{x}$ & & MS & ZB & SCIA 1986.073.PIS565 \\
\hline Pogonias cromis (Linnaeus, 1766$) * / \uparrow$ & WA & $\mathrm{x}$ & & $\mathrm{x}$ & MS & $\mathrm{ZB}$ & SCIA 1999.108.PIS600 \\
\hline Stellifer brasiliensis (Schultz, 1945) & $\mathrm{Br}$ & $\mathrm{x}$ & & & MM & & SCIA 1982.007.PIS499 \\
\hline Stellifer rastrifer (Jordan, 1889)* & $\mathrm{Br}+\mathrm{SSWA}$ & $\mathrm{x}$ & $\mathrm{x}$ & $\mathrm{x}$ & MM & ZB & SCIA 1984.066.PIS558 \\
\hline Stellifer stellifer (Bloch, 1790)\# & $\mathrm{Br}$ & $\mathrm{x}$ & & & MS & & \\
\hline Umbrina canosai Berg, $1895 \dagger \dagger$ & SSWA & $\mathrm{x}$ & & & MS & ZB & SCIA 2003.131.PIS623 \\
\hline Umbrina coroides Cuvier, $1830^{*}$ & WA & $\mathrm{x}$ & $\mathrm{x}$ & & MS & $\mathrm{ZB}$ & SCIA 1988.091.PIS583 \\
\hline \multicolumn{8}{|l|}{ Ophichthidae } \\
\hline Ophichthus cylindroideus (Ranzani, 1839)* & WA & $\mathrm{x}$ & & & & & OPHIC 1980.003.1127 \\
\hline Ophichthus gomesii (Castelnau, 1855)* & WA & $\mathrm{x}$ & $\mathrm{x}$ & $\mathrm{x}$ & MS & & OPHIC 1986.004.1128 \\
\hline \multicolumn{8}{|l|}{ Atheriniformes } \\
\hline \multicolumn{8}{|l|}{ Atherinopsidae } \\
\hline Atherinella brasiliensis (Quoy \& Gaimard, 1825)* & $\mathrm{Ca}+\mathrm{Br}$ & $\mathrm{x}$ & $\mathrm{x}$ & $\mathrm{x}$ & ES & OP & ATHE 1987.009.644 \\
\hline Odontesthes argentinensis (Valenciennes, 1835) & SSWA & $\mathrm{x}$ & $\mathrm{x}$ & & & & ATHE 2011.075.1135 \\
\hline \multicolumn{8}{|l|}{ Aulopiformes } \\
\hline \multicolumn{8}{|l|}{ Synodontidae } \\
\hline Synodus foetens (Linnaeus, 1766)* & WA & $\mathrm{x}$ & $\mathrm{x}$ & $\mathrm{x}$ & MS & PV & SYNO 1988. 004.481 \\
\hline \multicolumn{8}{|l|}{ Batrachoidiformes } \\
\hline \multicolumn{8}{|l|}{ Batrachoididae } \\
\hline Porichthys porosissimus (Cuvier,1829) & SSWA & $\mathrm{x}$ & & & MM & ZB & BATRA 1984.009.109 \\
\hline
\end{tabular}


Continuation Table 1.

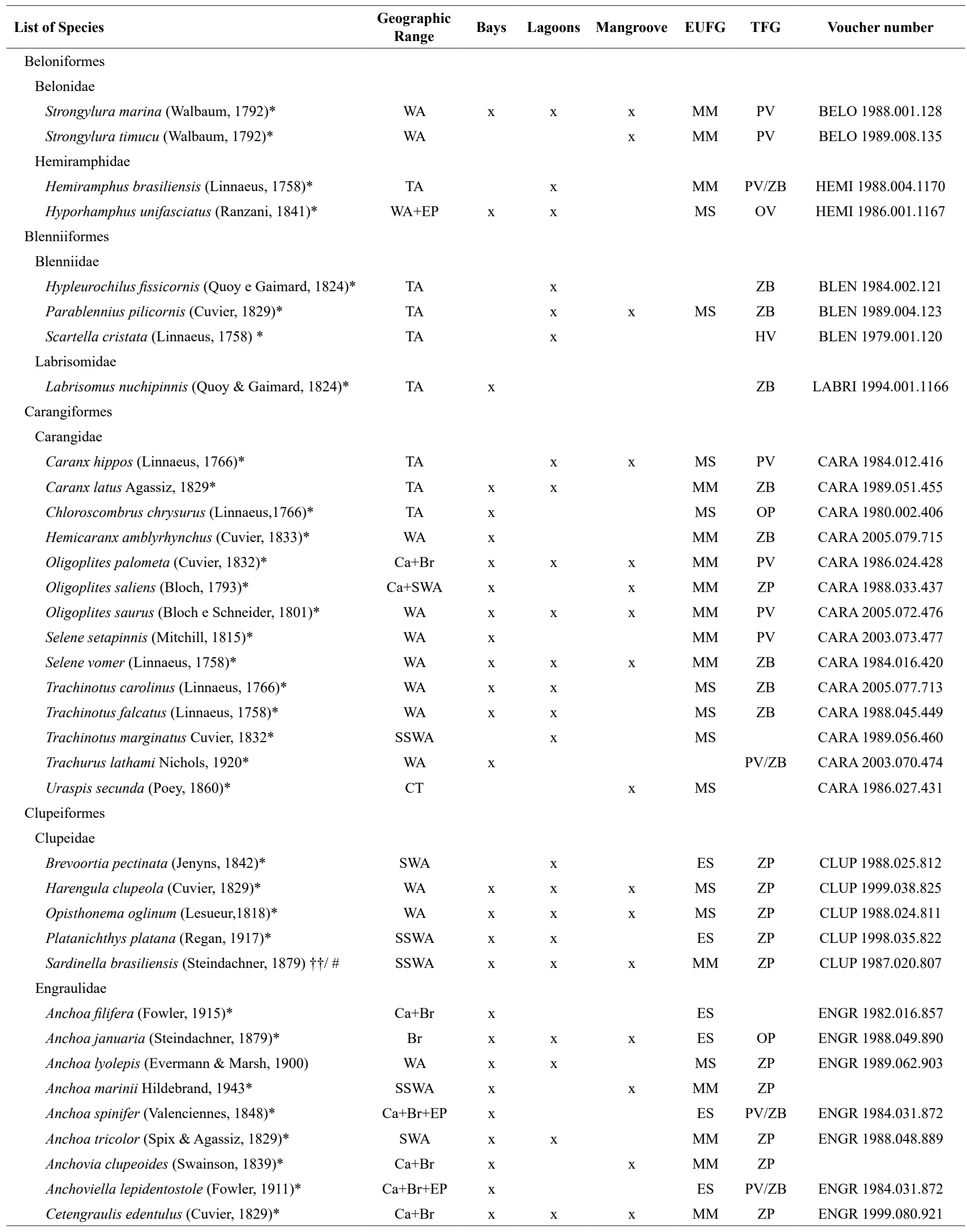


Ribeiro, G.C. et al.

Continuation Table 1.

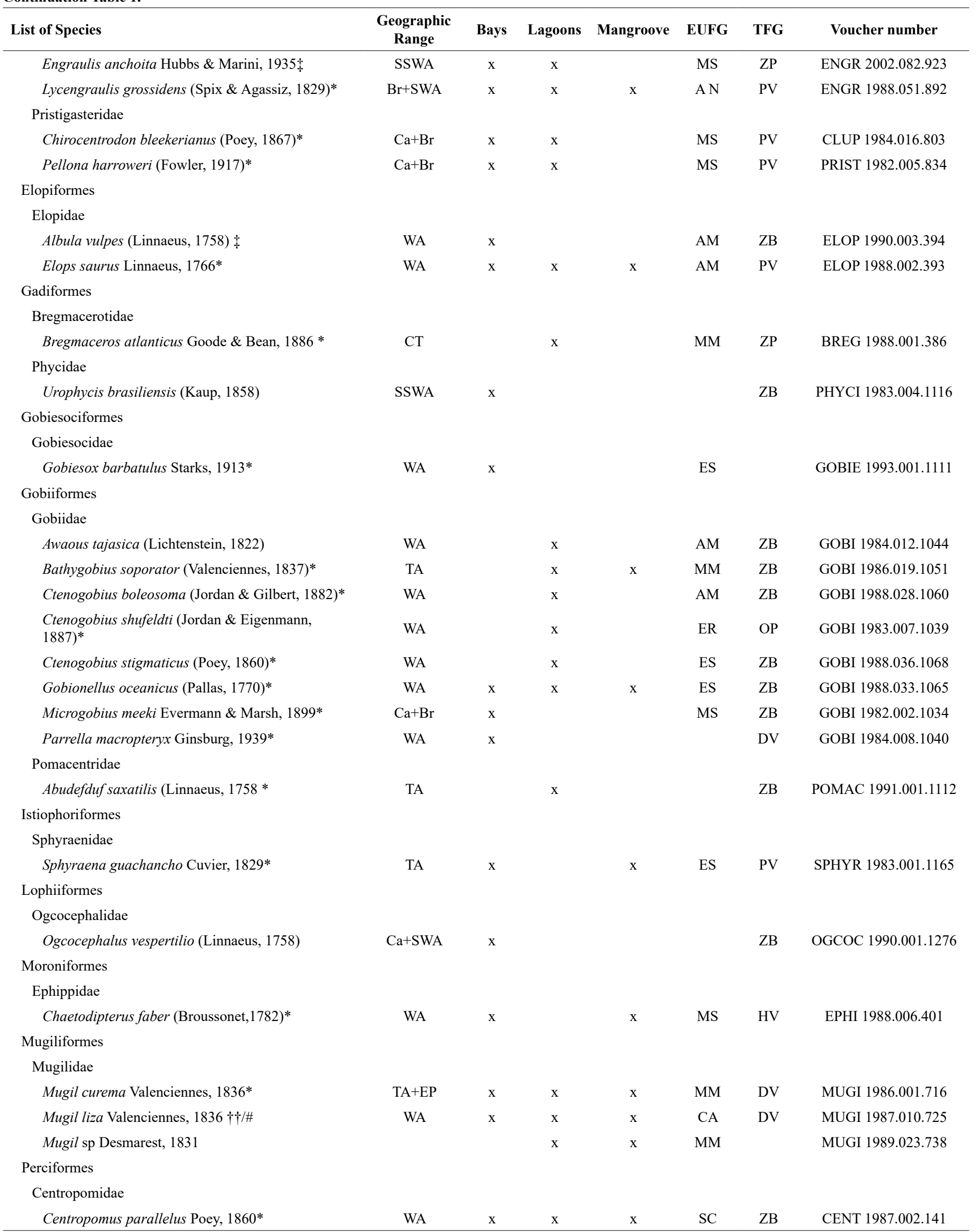


Continuation Table 1.

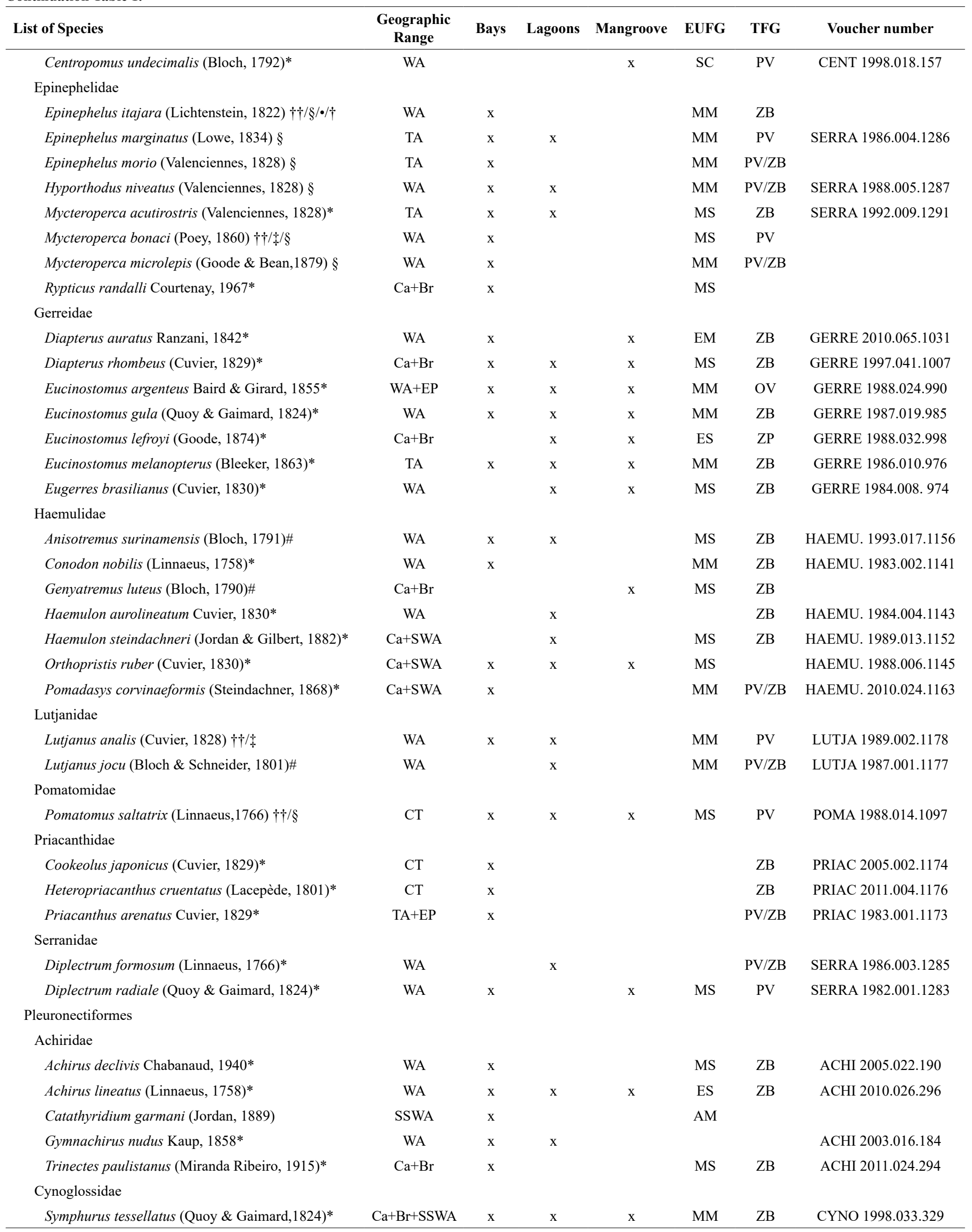


Continuation Table 1.

\begin{tabular}{|c|c|c|c|c|c|c|c|}
\hline List of Species & $\begin{array}{c}\text { Geographic } \\
\text { Range }\end{array}$ & Bays & Lagoons & Mangroove & EUFG & TFG & Voucher number \\
\hline \multicolumn{8}{|l|}{ Paralichthyidae } \\
\hline Citharichthys arenaceus Evermann \& Marsh, 1900* & WA & & & $\mathrm{x}$ & MS & ZB & PARA 1988.017. PIS 943 \\
\hline Citharichthys macrops Dresel,1885* & WA & $\mathrm{x}$ & & $\mathrm{x}$ & MS & ZB & PARA 2002.036. PIS 962 \\
\hline Citharichthys spilopterus Günter, 1862* & WA & $\mathrm{x}$ & $\mathrm{x}$ & $\mathrm{x}$ & ES & $\mathrm{ZB}$ & PARA 1982.003. PIS 929 \\
\hline Etropus crossotus Jordan \& Gilbert, $1882 *$ & $\mathrm{WA}+\mathrm{EP}$ & $\mathrm{x}$ & & $\mathrm{x}$ & MM & $\mathrm{ZB}$ & PARA 1983.010. PIS 936 \\
\hline Paralichthys orbignyanus (Valenciennes, 1839) & SSWA & $\mathrm{x}$ & & & MM & $\mathrm{ZB}$ & \\
\hline Paralichthys patagonicus Jordan, 1889 & SSWA+EP & $\mathrm{x}$ & & & & $\mathrm{PV}$ & PARA 2002.040. PIS 966 \\
\hline \multicolumn{8}{|l|}{ Pleuronectidae } \\
\hline Oncopterus darwinii Steindachner, 1874 & SSWA & $\mathrm{x}$ & & & MS & $\mathrm{ZB}$ & PLEUR. 2012.001.925 \\
\hline \multicolumn{8}{|l|}{ Scombriformes } \\
\hline $\begin{array}{l}\text { Scomberomorus brasiliensis (Colete, Russo \& } \\
\text { Zavalla-Camim, 1978) * }\end{array}$ & $\mathrm{Ca}+\mathrm{Br}$ & $\mathrm{x}$ & & $\mathrm{x}$ & MS & PV & SCOMB 2011.001.1194 \\
\hline \multicolumn{8}{|l|}{ Trichiuridae } \\
\hline Trichiurus lepturus Linnaeus, 1758* & $\mathrm{CT}$ & $\mathrm{x}$ & & $\mathrm{x}$ & MS & PV & TRICH 2012.013.1217 \\
\hline \multicolumn{8}{|l|}{ Scorpaeniformes } \\
\hline \multicolumn{8}{|l|}{ Scorpaenidae } \\
\hline Scorpaena isthmensis Meek \& Hildebrand, 1928* & WA & $\mathrm{x}$ & & & MS & & SCORP 1982.001.1136 \\
\hline Scorpaena plumieri Bloch, 1789* & WA & $\mathrm{x}$ & $\mathrm{x}$ & & & $\mathrm{PV} / \mathrm{ZB}$ & SCORP 1987.002 .1137 \\
\hline \multicolumn{8}{|l|}{ Triglidae } \\
\hline \multicolumn{8}{|l|}{ Ariidae } \\
\hline Genidens genidens (Cuvier, 1829)* & SSWA & $\mathrm{x}$ & $\mathrm{x}$ & $\mathrm{x}$ & MM & ZB & ARII 1987.024.214 \\
\hline \multicolumn{8}{|l|}{ Spariformes } \\
\hline \multicolumn{8}{|l|}{ Lobotidae } \\
\hline Lobotes surinamensis (Bloch, 1790)* & $\mathrm{CT}$ & & $\mathrm{x}$ & & MS & ZB & \\
\hline \multicolumn{8}{|l|}{ Sparidae } \\
\hline Archosargus rhomboidalis (Linnaeus, 1758)* & WA & $\mathrm{x}$ & $\mathrm{x}$ & $\mathrm{x}$ & MS & ZB & SPAR 1989.012.774 \\
\hline Diplodus argenteus (Valenciennes, 1830)* & SWA & $\mathrm{x}$ & $\mathrm{x}$ & & MM & ZB & SPAR 1988.006.768 \\
\hline \multicolumn{8}{|l|}{ Syngnathiformes } \\
\hline \multicolumn{8}{|l|}{ Dactylopteridae } \\
\hline Dactylopterus volitans (Linnaeus, 1758)* & TA & $\mathrm{x}$ & $\mathrm{x}$ & $\mathrm{x}$ & MS & ZB & DACT 1989.003 .390 \\
\hline \multicolumn{8}{|l|}{ Fistulariidae } \\
\hline Fistularia tabacaria Linnaeus, $1758^{*}$ & $\mathrm{TA}$ & & $\mathrm{x}$ & & MM & PV & FISTU 1993.001 .787 \\
\hline \multicolumn{8}{|l|}{ Syngnathidae } \\
\hline Hippocampus reidi Ginsburg, $1933 \dagger \dagger / \$ / / \S$ & WA & $\mathrm{x}$ & $\mathrm{x}$ & & MM & $\mathrm{ZP}$ & SYNG 1992.003 .490 \\
\hline Syngnathus folletti Herald, 1942* & SWA & $\mathrm{x}$ & $\mathrm{x}$ & & MS & & SYNG 1989.002.489 \\
\hline \multicolumn{8}{|l|}{ Tetraodontiformes } \\
\hline \multicolumn{8}{|l|}{ Balistidae } \\
\hline Balistes capriscus Gmelin, $1789 \S$ & $\mathrm{TA}$ & & $\mathrm{x}$ & & & & BALI 1981.002.1186 \\
\hline
\end{tabular}


Continuation Table 1.

\begin{tabular}{|c|c|c|c|c|c|c|c|}
\hline List of Species & $\begin{array}{c}\text { Geographic } \\
\text { Range }\end{array}$ & Bays & Lagoons & Mangroove & EUFG & TFG & Voucher number \\
\hline \multicolumn{8}{|l|}{ Diodontidae } \\
\hline Chilomycterus spinosus spinosus (Linnaeus, 1758) & SWA & $\mathrm{x}$ & & $\mathrm{x}$ & MM & ZB & DIOD 1999.002.1104 \\
\hline \multicolumn{8}{|l|}{ Monacanthidae } \\
\hline Aluterus schoepfii (Walbaum, 1792)* & TA & & $\mathrm{x}$ & & & HV & MONA. 1988.002.1188 \\
\hline Stephanolepis hispidus (Linnaeus, 1766)* & TA & $\mathrm{x}$ & $\mathrm{x}$ & & MS & ZB & MONA. 1987.001.1187 \\
\hline \multicolumn{8}{|l|}{ Ostraciidae } \\
\hline Lactophrys trigonus (Linnaeus, 1758)* & WA & $\mathrm{x}$ & & & & ZB & OSTRA 2001.001 .1124 \\
\hline \multicolumn{8}{|l|}{ Tetraodontidae } \\
\hline Lagocephalus laevigatus (Linnaeus, 1766)* & WA & $\mathrm{x}$ & $\mathrm{x}$ & $\mathrm{x}$ & MM & $\mathrm{PV} / \mathrm{ZB}$ & TETRA 1991.019.1238 \\
\hline Sphoeroides spengleri (Bloch, 1785)* & TA & $\mathrm{x}$ & $\mathrm{x}$ & $\mathrm{x}$ & & ZB & TETRA 2010.031.1250 \\
\hline Sphoeroides testudineus (Linnaeus, 1758)* & WA & $\mathrm{x}$ & $\mathrm{x}$ & $\mathrm{x}$ & ES & $\mathrm{ZB}$ & TETRA 1998.024.1243 \\
\hline Sphoeroides tyleri Shipp, 1972 & $\mathrm{Br}$ & $\mathrm{x}$ & & & & ZB & TETRA 2004.028.1247 \\
\hline \multicolumn{8}{|l|}{ Trachiniformes } \\
\hline \multicolumn{8}{|l|}{ Uranoscopidae } \\
\hline Astrocopus y-graecum (Cuvier, 1829) & WA & $\mathrm{x}$ & & & MS & PV & URANO 2012.001.1203 \\
\hline \multicolumn{8}{|l|}{ Chondrichthyes } \\
\hline \multicolumn{8}{|l|}{ Myliobatiformes } \\
\hline \multicolumn{8}{|l|}{ Gymnuridae } \\
\hline \multicolumn{8}{|l|}{ Pristiformes } \\
\hline \multicolumn{8}{|l|}{ Torpediniformes } \\
\hline \multicolumn{8}{|l|}{ Narcinidae } \\
\hline Narcine brasiliensis (Olfers, 1831)\# & WA & & $\mathrm{x}$ & & MS & ZB & NARCI 1991.001.1277 \\
\hline
\end{tabular}

Pogonias cromis and Genidens barbus as endangered. Only two species (Epinephelus itajara - endangered; Hippocampus reidi - vulnerable) are listed in the regional extinction list (CONSEMA, 2011) (Table 1).

\section{Discussion}

In Western Atlantic estuaries, Sciaenidae, Engraulidae, Ariidae and Gerreidae are among the seven most representative families in abundance in bottom trawling (Vieira \& Musick 1994). Members of the families Sciaenidae and Engraulidae possess a wide tolerance to variations in salinity and temperature, which favors their occurrence in both estuarine and coastal waters along the Atlantic coast of South America (Camargo \& Isaac 2003). The total species richness reported for the Island of Santa Catarina was relatively high when compared to other areas, such as Guaratuba Bay (southern coast of Paraná) (87 spp.; Chaves \& Corrêa 1998, Chaves \& Vendel 2001) and Babitonga Bay (northern coast of Santa Catarina) (150 spp.; Vilar et al. 2011). These differences may have arisen because of differences in area among sites (Guaratuba Bay- $48 \mathrm{~km}^{2}$, Babitonga Bay-130 km², Island of Santa Catarina- $431 \mathrm{~km}^{2}$ ) and/or because of the higher sampling effort in our study area (in number of samplings and variety of environments).

In terms of number of species, the total species richness of the Island of Santa Catarina is relatively higher than that of most of the coastal areas from the Western Atlantic [Paranaguá Estuarine Complex, southern Brazil (213 spp.; Passos et al. 2012); Guaratuba Bay, southern Brazil (87 spp.; Chaves \& Corrêa 1998, Chaves \& Vendel 2001); Rio da Prata estuary, northern Argentina (60 spp.; Jaureguizar et al. 2004); Caeté River estuary, northern Brazil (120 spp.; Marceniuk et al. 2017); Sergipe River estuary (136 spp.; Alcântara 2006); Curuçá estuary (98 spp.; Hercos 2006, Giarrizzo \& Krumme 2007, Sarpedonti et al. 2008); Babitonga Bay (152 spp.; Vilar et al. 2011); Mataripe estuary (36 spp.; Dias et al. 2011); Paraguaçu River estuary (124 spp.; Reis-Filho et al. 2010), estuaries of northern Espírito Santo (57 spp.; Hostim-Silva et al. 2013)], and other tropical areas (number of species varying from 81 
to 197; Blaber 2002), including estuaries of the biogeographic zones of the Indo-Pacific. Differences in species richness and composition may be difficult to explain since multiple specific factors can drive fish assemblage patterns, such as habitat diversity, rainfall patterns and hydrographic and oceanographic patterns. These factors act at distinct intensities and scales, leading to differences in fauna composition and richness between areas. However, these differences may be a result of insufficient sampling in the contrasting environments and/or the use of distinct fishing gear in tropical areas around the world (Blaber 2002).

The majority of the species are widely distributed in the Western Atlantic, but the segregation of species into two groups with distinct distribution is also evident. One includes species that occur in the Caribbean and in the Brazilian Province, and have affinities with the Caribbean fauna. The other, which encompasses species that occur in the Southwestern Atlantic, possesses temperate affinities and species similar to those that occur in Argentina and Uruguay.

This study provides a checklist of fish species from the Island of Santa Catarina based on a robust dataset constructed over the last 30 years. Once this study considered the diverse environments of the island (bays, lagoons and mangroves), it increased, therefore, the detectability of the species from this region. The ichthyofauna of the Island of Santa Catarina is composed by species with affinities with the tropical fauna of the Brazilian coast and the temperate fauna from Argentina and Uruguay. The species richness of the study area is relatively high when compared to other areas from Western Atlantic, emphasizing the importance of this region for the conservation of the aquatic biodiversity. In addition, some of the species reported in this study are listed in inventories of conservation status. Thus, it is suggested the monitoring of this fauna and more regional samplings for gathering more information about fish species from the Island of Santa Catarina (including the invasive species), mainly for conservation and management proposals.

\section{Author Contributions}

Gisela Costa Ribeiro: Contribution to data collection.

André Pereira Cattani: Contribution to data analysis and interpretation; Contribution to manuscript preparation.

Mauricio Hostim-Silva: Contribution to data collection.

Leandro Clezar: Contribution to data collection.

Ana Carolina dos Passos: Substantial contribution in the concept and design of the study; Contribution to manuscript preparation.

Marcelo Soeth: Substantial contribution in the concept and design of the study; Contribution to critical revision, adding intelectual content.

Olímpio Rafael Cardoso: Contribution to manuscript preparation; Contribution to critical revision, adding intelectual content.

Henry Louis Spach: Substantial contribution in the concept and design of the study; Contribution to manuscript preparation; Contribution to critical revision, adding intelectual content.

\section{Conflicts of interest}

The authors declare that they have no conflict of interest related to the publication of this manuscript.

\section{References}

ABREU DE CASTILHOS, J. \& GRÉ, J.C.R. 1997. Praias da Ilha de Santa Catarina: caracterização morfológica e problemas de erosão costeira. In Colóquio Franco-brasileiro sobre manejo costeiro da Ilha de Santa Catarina. Florianópolis. Florianópolis: UFSC-Université Bordeaux 1.

ALCÂNTARA, A.V. 2006. A ictiofauna do estuário do Rio Sergipe. in ALVES, J.P.H. (ed.). Rio Sergipe: importância, vulnerabilidade e preservação. Sergipe, Editora UFS, p. 111-142.

BARLETTA, M. \& BLABER, S.J.M. 2007. Comparision of fish assemblages and guilds in tropical habitats of the Embley (Indo-West Pacific) and Caeté (Western Atlantic) estuaries. B Mar Sci. 80(3): 647-680.

BARLETTA, M., JAUREGUIZAR, A.J., BAIGUN, C., FONTOURA, N.F, AGOSTINHO, A.A., ALMEIDA-VAL, V.M.F., VAL, A.L., TORRES, R.A., JIMENES-SEGURA, GIARRIZZO, L.F.T., FABRÉ, N.N., BATISTA, V.S., LASSO, C., TAPHORN, D.C., COSTA, M.F., CHAVES, P.T., VIEIRA, J.P, CORRÊA, M.F.M. 2010. Fish and aquatic habitat conservation in South America: a continental overview with emphasis on neotropical systems. J Fish Biol. 76(9): 2118-2176.

BETANCUR-R, R., WILEY, E.O., ARRATIA, G., ACERO, A., BAILL, N., MIYA, M., LECOINTRE, G., ORTI, G. 2017. Phylogenetic classification of bony fishes. BMC Evol Biol. 17: 162.

BLABER, S.J.M. 2002. Fish in hot water: the challenges facing fish and fisheries research in tropical estuaries. J Fish Biol. 61(sA): 1-20.

CARVALHO-FILHO, A., SANTOS, S., SAMPAIO, I. 2010. Macrodon atricauda (Günther, 1880) (Perciformes: Sciaenidae), a valid species from the southwestern Atlantic, with comments on its conservation. Zootaxa. 2519: 48-58.

CARTAGENA, B.F.C., HOSTIM-SILVA, M., SPACH, H.L. 2011. Distribuição espacial da ictiofauna demersal no Saco dos Limões (baía Sul, Florianópolis, SC). Bioikos. 25(2): 117-126

CATTANI, A.P., DAURA JORGE, F.G., RIBEIRO, G.C., WEDWKIN, L., SIMÕES-LOPES, P.C., RUPEL, G., SPACH, H.L.. 2016a. Fish assemblage in a costal bay afjacent to a network of marine protect áreas in Southern Brazil. Braz J Oceanogr. 64(3): 295-308.

CATTANI, A., RIBEIRO, G.C., MARCON, E., SOETH, M., HOSTIMSILVA, M., CLEZAR, L., SPACH, H.L. 2016b. Fish assemblage dynamics in the Ratones River Mangrove, State of Santa Catarina, Brasil. Panam JAS. 11(4): 324-335.

CATTANI, A., CARDOSO, O.R., RIBEIRO, G.C., SOETH, M., HOSTIMSILVA, M., CLEZAR, L., PICHLER, H.A., SPACH, H.L. 2018. Fish species richness in shallow environments of Island of Santa Catrina, Southern Brazil. Revista CEPSUL: Biodiversidade e Conservação Marinha. 7: 1-16.

CHAVES, P.T. \& CORRÊA, M.F.M. 1998. Composição ictiofaunística da área de manguezal da Baía de Guaratuba, Estado do Paraná, Brasil. Rev Bras Zool. 15(1): 195-202.

CHAVES, P.T. \& VENDEL, A.L. 2001. Nota complementar sobre a composição ictiofaunística da Baía de Guaratuba, Paraná, Brasil. Rev Bras Zool. 18(1): 349-352.

CLEZAR, L., HOSTIM-SILVA, M., RIBEIRO, G.C. 1998. Comunidade de Peixes do Manguezal do Itacorubi, Ilha de Santa Catarina, SC, Brasil; pp. 205-216, in: SIERRA DE LEDO, B. and SORIANO-SIERRA, E.J. (Eds.). Ecologia e Gerenciamento do Manguezal do Itacorubi. Florianópolis: NEMAR/CCB/UFSC. SDM/FEPEMA.

CONSEMA. 2011. RESOLUÇÃO CONSEMA Nº 002, DE 06 DE DEZEMBRO DE 2011. Lista Oficial de Espécies da Fauna Ameaçadas de Extinção no Estado de Santa Catarina. Accessible at: http://media.wix.com/ugd/4e96b 1_7aee52da52ca9f5b16f823476a0b1cfc.pdf (last access in 13/abr/2018).

CRAIG, M.T. \& HASTINGS, P.A. 2007. A molecular phylogeny of the groupers of the subfamily Epinephelinae (Serranidae) with a revised classification of Epinephelini. Ichthiol Res. 54: 1-17.

DAURA JORGE, F.G. 2007. A dinâmica predador-presa e o uso espaçotemporal do boto-cinza, Sotalia guianensis (Cetacea, Delphinidae), na Baía Norte da Ilha de Santa Catarina, sul do Brasil. M.Sc. dissertation, Curitiba: Universidade Federal do Paraná. 106 pp. 
DIAS, J.F., GONÇALVES, A.M., FERNANDEZ, W.S., SILBIGER, H.L.N., FIADI, C.B., SCHMIDT, T.C.S. 2011. Ichthyofauna in an estuary of the Mataripe area, Todos os Santos Bay, Bahia, Brazil. Braz J Oceanogr. 59(1): 75-95.

ELLIOTT, M.; WHITFIELD, A.K., POTTER, I.C., BLABER, S.J.M., CYRUS, D.P., NORDLIE, F.G. \& HARRISON, T.D. 2007. The guild approach to categorizing estuarine fish assemblages: a global review. Fish Fish. 8(3): 241-268.

ESCHMEYER, W.N. 2013. Catalog of Fishes. California Academy of Sciences, San Francisco. Accessible at http://researcharchive.calacademy.org/research/ Ichthyology/catalog/fishcatmain.asp (last access on 03/jun/2017).

FIGUEIREDO, J.L., SALLES, A.C.R., RABELO, L.B. 2010. Sardinella brasiliensis (Steindachner, 1879) (Teleostei: Clupeidae), nome válido aplicado à sardinha verdadeira no sudeste do Brasil. Pap Avulsos Zool. 50(18): 281-283.

FLOETER, S.R., ROCHA, L.A., ROBERTSON, D.R., JOYEUX, J.C., SMITH-VANIZ, W.F., WIRTZ, P., EDWARDS, A.J., BARREIROS, J.P., FERREIRA, C.E.L., GASPARINI, J.L., BRITO, A., FALCÓN, J.M., BOWEN, B.W., BERNARDI, G.. 2008. Atlantic reef fish biogeography and evolution. J Biogeogr. 35: 22-47.

FONSECA, A., BRAGA, E.S., EICHLER, B.B.. 2002. Distribuição espacial dos nutrientes inorgânicos dissolvidos e da biomassa fitoplanctônica no sistema pelágico da lagoa da Conceição, Santa Catarina, Brasil. Atlântica. 24(2): 69-83

FROESE, R. \& PAULY, D. 2018. FishBase. World Wide Web electronic publication. Accessible at http://www.fishbase.org/home.htm (last access in 19/abr/2018).

GIARRIZZO, T. \& KRUMME, U. 2007. Spatial differences and seasonal cyclicity in the intertidal fish fauna from four mangrove creeks in a salinity zone of the Curuçá estuary, north Brazil. B Mar Sci. 80(3): 739-754.

HERCOS, A.P. 2006. Diversidade e variabilidade espaço-temporal da ictiofauna da região estuarina do rio Curuçá município de Curuçá, Pará, Brasil. M.Sc. dissertation. Belém: Universidade Federal do Pará. 123 pp.

HOSTIM-SILVA, M; LIMA, A.C., SPACH, H.L., PASSOS, A.C., SOUZA, J.D. 2013. Estuarine demersal fish assemblage from a transition region between the tropics and the subtropics of the South Atlantic. Biotemas. 26(3): 153-161.

IUCN. 2018. The IUCN red list of threatened species. International ed. IUCN Global Species Programme Red List Unit. Accessible at http://www. iucnredlist.org/ (last access in 25/feb/2019).

JAUREGUIZAR, A.J., MENNI, R., GUERRERO, R., LASTA, C. 2004. Environmental factors structuring fish communities of the Río de la Plata estuary. Fish Res. 66: 195-211.

LUIZ JR, O.J., CARVALHO-FILHO, A., FERREIRA, C.E.L., FLOETER, S.R., GASPARINI, J.L., SAZIMA, I. 2008. The reef fish assemblage of the Laje de Santos Marine State Park, Southwestern Atlantic: annotated checklist with comments on abundance, distribution, trophic structure, symbiotic associations, and conservation. Zootaxa. 1807: 1-25.

MARCENIUK, A.P., CAIRES, R.A, ROTUNDO, M.M, ALCANTARA, R.A.K, WOSIACKI, W.B. 2017. The icthyofauna (Teleostei) of the Rio Caeté estuary, northeast Pará, Brazil, with a species identification key from northern Brazilian coast. PanaJAS. 12(1): 31-79.

MENEZES, N.A., BUCKUP, P.A., FIGUEIREDO, J.L., MOURA, R.L. 2003. Catálogo de espécies de peixes marinhos do Brasil. São Paulo: Museu de Zoologia da Universidade de São Paulo. 159 pp.
MENEZES, N.A., OLIVEIRA, C., NIRCHIO, M.. 2010. An old taxonomic dilemma: the identity of the western south Atlantic lebranche mullet (Teleostei: Perciformes: Mugilidae). Zootaxa. 2519: 59-68.

MMA. 2016. Livro vermelho da fauna Brasileira ameaçada de extinção. Ministério do Meio Ambiente, Brasília, 142 pp. Accessible at: http://www. icmbio.gov.br/portal/images/stories/comunicacao/publicacoes/publicacoesdiversas/dcom_sumario_executivo_livro_vermelho_ed_2016.pdf (last access in 27/feb/2019).

NELSON, J.S., GRANDE, T.C., WILSON, M.H. 2016. Fishes of the World. 5 ed. John Wiley \& Sons, Hoboken.

NEMAR. 1999. Diagnóstico ambiental visando um programa de monitoramento da Lagoa do Peri, Ilha de Santa Catarina, SC. Núcleo de Estudos do Mar, Programa Institucional de Estudo de Sistemas Costeiros, Florianópolis: Universidade Federal de Santa Catarina. 352 pp.

PASSOS, A.C., CONTENTE, R.F., ARAÚJO, C.C.V., DAROS, F.A.L.M., SPACH, H.L., ABILHÔA, V., FÁ VARO, L.F. Fishes of Paranagua Estuarine Complex, South West Atlantic. Biota Neotropica. 12(3): 226238. http://dx.doi.org/10.1590/S1676-06032012000300022 (last access on $10 /$ set/2018).

RIBEIRO, G.C., CLEZAR, L., HOSTIM-SILVA, M., FILOMENO, M.J.B., AGUIAR, J.B.S. 1997. Ictiofauna da lagoa da Conceição e área costeira adjacente, Ilha de Santa Catarina, SC, Brasil. In Colóquio Franco-brasileiro sobre manejo costeiro da Ilha de Santa Catarina. Florianópolis. Florianópolis: UFSC-Université Bordeaux 1.

RIBEIRO, G.C.; CLEZAR, L., HOSTIM-SILVA, M., 1999. Comunidade íctica, sua variação espacial e sazonal na Lagoa da Conceição e área adjacente, Ilha de Santa Catarina, SC, Brasil; pp. 261-273, in: SIERRA DE LEDO, B. and SORIANO-SIERRA, E.J. (Eds.). O Ecossistema da Lagoa da Conceição. Florianópolis: NEMAR/CCB/UFSC. SDM/FEPEMA.

REIS-FILHO, J.A., NUNES, J.A.C.C., FERREIRA, A. Estuarine ichthyofauna of the Paraguaçu River, Todos os Santos Bay, Bahia, Brazil. Biota Neotropica. 10(4): 301-312. http://dx.doi.org/10.1590/S1676-06032010000400034 (last access on $05 /$ out $/ 2018$ ).

SARPEDONTI, V., ANUNCIAÇÃO, E.M.S., NAHUM, V.J.I. 2008. Ichthyoplankton variation in two mangrove creeks of the Curuçá estuary, Pará, Brazil. Ecotropicos. 21(1):1-12.

SIERRA DE LEDO, B. 1997. Subsídios ecológicos para um plano de gestão integrada na zona costeira da Ilha de Santa Catarina. In Colóquio Francobrasileiro sobre manejo costeiro da Ilha de Santa Catarina. Florianópolis. Florianópolis: UFSC-Université Bordeaux 1.

SMITH, W.L. \& CRAIG, M.T. 2007. Casting the Percomorph net widely: the importance of broad taxonomic sampling in the search for the placement of the serranid and percid fishes. Copeia 2007(1): 35-55.

SOETH, M., RIBEIRO, G.C., SPACH, H.L., CATTANI, A.P. \& ANDRADE, V.K. 2015. Comparison of the temporal and taxonomic patterns of ichthyofauna captured with a fyke net in two sheltered environments in southern Brazil. Lat. Am. J. Aquat. Res. 43(1): 107-122. http://dx.doi. org/10.3856/vol43-issue1-fulltext-10 (last access on 10/apr/2019).

SORIANO-SIERRA, E.J. 1997. Fluxos de maré e interferências antrópicas à hidrodinâmica no interior de um manguezal naturalmente estressado: estudo de caso. In Colóquio Franco-brasileiro sobre manejo costeiro da Ilha de Santa Catarina. Florianópolis. Florianópolis: UFSC-Université Bordeaux 1.

VIEIRA, J.P. \& MUSICK, J.A.. 1994. Fish faunal composition in warm-temperate and tropical estuaries of western Atlantic. Atlântica. 16: 31-53.

VILAR, C.C., SPACH, H.L., SANTOS, L.O. 2011. Fish fauna of Baia da Babitonga (southern Brazil), with remarks on species abundance, ontogenic stage and conservation status. Zootaxa. 2734: 40-52. 
Ribeiro, G.C. et al.

\section{Erratum}

\section{Erratum: Ichthyofauna marine of the Island of Santa Catarina, Southern Brazil: checklist with comments on the species}

In the article "Ichthyofauna marine of the Island of Santa Catarina, Southern Brazil: checklist with comments on the species" with the DOI code number http://dx.doi.org/10.1590/1676-0611-BN-2018-0684, published at Biota Neotropica 19(3): e20180684, the title should be

Marine ichthyofauna of Santa Catarina Island, Southern Brazil: checklist with comments on the species

Instead of:

Ichthyofauna marine of the Island of Santa Catarina, Southern Brazil: checklist with comments on the species 